\title{
Manufacture of student chair in composite material reinforced with fique fiber
}

\author{
Fabricación de silla estudiantil en material compuesto reforzado con fibra de fique
}

\author{
S. Gómez-Suarez ; E. Córdoba-Tuta iD , C. B. Vega-Mesa iD ; S. Gómez-Becerra iD \\ DOI: https://doi.org/10.22517/23447214.24509 \\ Artículo de investigación científica y tecnológica
}

\begin{abstract}
The use of natural fibers as reinforcement for composite materials is on the rise due to the need to reduce environmental damage and manufacture sustainable products. One of the fibers used for this purpose is fique fiber. This article describes the manufacture of a student chair with fique fiberreinforced composite material. To choose the amount of reinforcement to be used in the elaboration of the chair, the mechanical characterization of several composites with different percentages of the fiber was carried out, where it was found that both the flexural and tensile properties increased with a higher insertion of fique. The selected material was analyzed morphologically with optical microscopy, finding that there was good adhesion between the fiber and the matrix. A simulation with finite elements showed that the chair would resist a load of $100 \mathrm{~kg}$. The student chair was manufactured using the Hand Lay Up technique with material composed of fique fiber and polyester resin.
\end{abstract}

Index Terms - Composite, Fique, Mechanical characterization, Natural Fiber.

Resumen-El uso de fibras naturales como refuerzo de materiales compuestos esta aumentado debido a la necesidad de reducir el daño ambiental y manufacturar productos sustentables. Una de las fibras utilizadas para este fin es la fibra de fique. El presente artículo describe la fabricación de una silla estudiantil con material compuesto reforzado con fibra de fique. Para la elección de la cantidad del refuerzo a utilizar en la elaboración de la silla se realizó caracterización mecánica de diversos compuestos con diferentes porcentajes de la fibra donde se encontró que tanto las propiedades de flexión y tensión aumentaron con mayor inserción de fique. Se analizó morfológicamente con microscopia óptica el material seleccionado encontrándose que existe buena adhesión entra la fibra y la matriz. Una simulación con elementos finitos permitió evidenciar que la silla resistiría una carga de $100 \mathrm{~kg}$. La

This manuscript was sent on September 07, 2020 and accepted on November $11,2020$.

This work was supported by the Universidad Pontificia Bolivariana.

S. Gómez S. Author is with the Mechanical Engineering Department, Universidad Pontificia Bolivariana, $\mathrm{Km} 7$ autopista via Piedecuesta, Floridablanca, Santander, Colombia, (e-mail: sergio.gomezs@upb.edu.co)

E. Cordoba T. Author is with the Mechanical Engineering Department, Universidad Pontificia Bolivariana, Km 7 autopista via Piedecuesta, Floridablanca, Santander, Colombia, (e-mail: edwin.cordoba@upb.edu.co) silla estudiantil se manufacturó por medio de la técnica Hand Lay Up con material compuesto de fibra de fique y resina de poliéster

Palabras claves-Caracterización mecánica, Fibra Natural, Fique, Material Compuesto

\section{INTRODUCTION}

$\mathrm{C}$ OMPOSITE materials are defined as the heterogeneous combination of two or more materials at the macroscopic level in order to achieve better properties than individually [1].

In the manufacture of these composite materials, fibers of synthetic origin were usually used as reinforcement, however, recently natural fibers have been replaced because they exhibit good properties such as high mechanical resistance, excellent thermal insulation, good flexibility and biodegradability [2].

Additionally, there is a great need to replace unsustainable products with sustainable products due to the limited amount of conventional energy resources and damage to the environment, which has promoted the use of renewable raw materials such as natural fibers for the development of new components [3].

One of these natural fibers is fique fiber, which is grown in South American countries such as Colombia, Brazil, Ecuador, Venezuela, Costa Rica, and the Antilles. The main application of the fiber is the use of long fibers to make coffee bags and ropes, however, it is also obtained in other presentations such as short fibers and woven [4].

Diverse works of manufacture and characterization of composite materials made with fique fiber are found in the literature, obtaining mainly their mechanical, thermal, morphological and dynamic properties [5]-[9]. However, there is not enough evidence of use in industrial applications, except for Delvasto et al. [10], who manufactured corrugated composite sheets with cement matrix and fique fiber

C. Vega M. Author is with the Mechanical Engineering Department, Universidad Pontificia Bolivariana, Km 7 autopista via Piedecuesta, Floridablanca, Santander, Colombia, (e-mail: christian.vega.2015@upb.edu.co)

S. Gómez B. Author is with the Mechanical Engineering Department, Universidad Pontificia Bolivariana, Km 7 autopista via Piedecuesta, Floridablanca, Santander, Colombia, (e-mail: sergio.gomez.2015@upb.edu.co) 
reinforcement to be used in the construction sector.

It is for this reason that this article describes the manufacture of a student chair with composite material reinforced with fique fiber, characterizing the material mechanically and morphologically by means of the flexural, tensile and optical microscopy tests accompanied by a simulation of finite elements that allowed evidencing that the chair would resist a load of $100 \mathrm{~kg}$.

\section{MATERIALS AND METHODS}

\section{A. Materials}

Fique fiber in random configuration were used as reinforcement for the composite materials that make up the back, seat, and armrests of the chair. They were supplied by the foundation San Lorenzo in Barichara, Santander Colombia. Fig. 1 shows the fiber under an optical microscope at 50X.

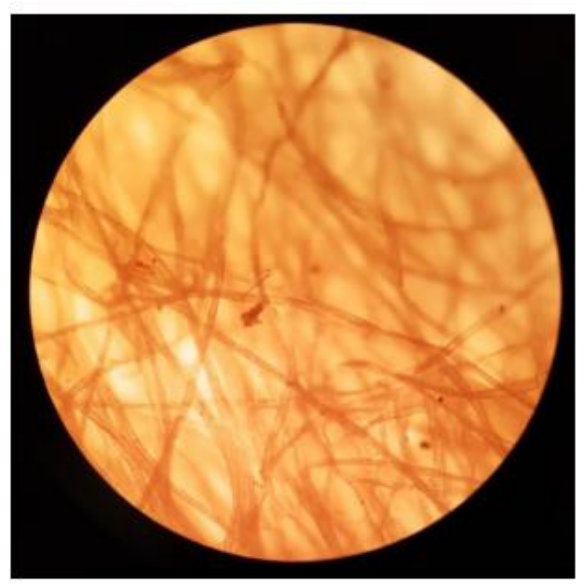

Fig. 1. Fique fibers seen with 50X magnification.

The fibers have a length of $1.76 \pm 0.53 \mathrm{~mm}$ and a diameter of $0.0253 \pm 0.0033 \mathrm{~mm}$, as reported in study by Gómez et al. [11], where the same reinforcement was used in the same random configuration.

In the fabrication of the chair support structure, fique fiber was used in woven configuration (See Fig. 2), which was obtained from a conventional sack used for coffee transportation.

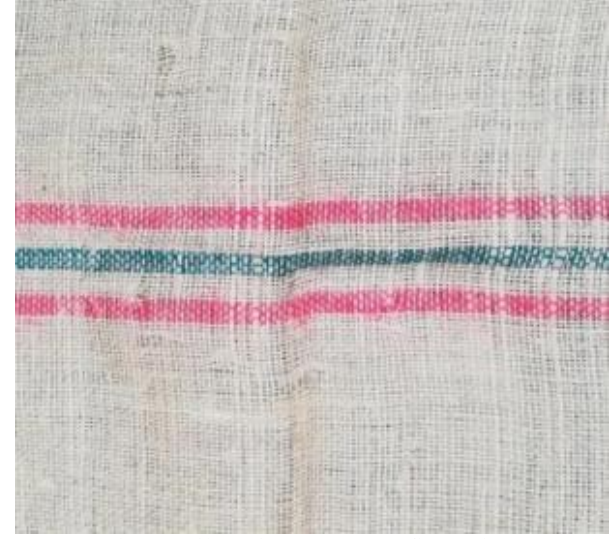

Fig. 2. Fibers in woven configuration.

The matrix for the different parts of the chair was polyester reference 102, acquired at the ingequimicas company in Bucaramanga, Santander, Colombia, being the one with the lowest viscosity available by the distributor, this in order to facilitate its handling and application. The percentage of catalyst resin by weight was 100: 2 respectively.

\section{B. Manufacture of specimens for characterization tests.}

Composite material specimens were made with three, four and five layers of fique reinforcement corresponding to $15.36 \%, 20.09 \%$ and $24.9 \%$ by weight, in order to determine the most suitable arrangement to use on the back, seat and armrests according to loads to flexural and tensile.

The specimens were manufactured according to the Hand Lay Up technique, placing layer after layer of fiberglass preimpregnated with polyester resin on an acrylic mold previously anointed with a release agent. Curing was carried out at room temperature for 48 hours.

The geometry of the specimens for the tensile test was established according to the ASTM D3039 / D3039M standard where measurements of $25 \mathrm{~cm}$ long by $2.5 \mathrm{~cm}$ wide by $2.5 \mathrm{~mm}$ thick are defined.

Regarding the flexural test, the dimensions of the specimens were established according to the ASTM D7264 / D7264M standard where the thickness-span ratio was 32: 1 respectively, and the width was $13 \mathrm{~mm}$. In Fig. 3 specimens manufactured for the flexural test are observed. 


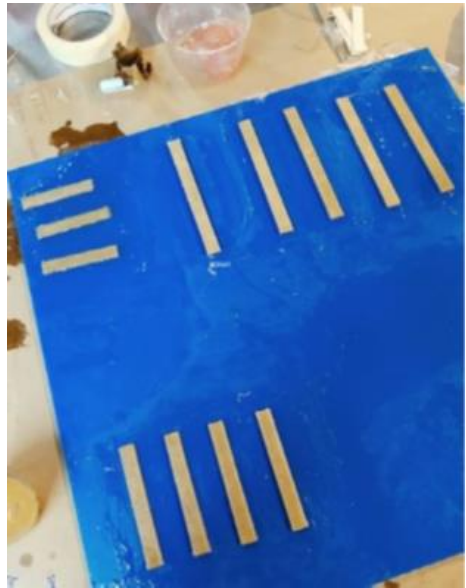

Fig. 3. Fique fiber specimens.

\section{Tensile test.}

The tensile test was carried out following the ASTM D3039/D3039M standard on a universal machine brand MTS model C43.104 of $10 \mathrm{kN}$ at a speed of $2 \mathrm{~mm} / \mathrm{min}$ with a temperature of $24.2{ }^{\circ} \mathrm{C} \pm 3{ }^{\circ} \mathrm{C}$. For each of the materials, five specimens were tested, considering the average of each of the properties.

\section{Flexural test.}

The flexural test was carried out according to the ASTM D7264/D7264M-15 standard by means of a universal machine MTS model C43.104 of $10 \mathrm{kN}$ at a speed of $1 \mathrm{~mm} / \mathrm{min}$ and a temperature of $24.3{ }^{\circ} \mathrm{C} \pm 3.2^{\circ} \mathrm{C}$.

The flexural mechanical characterization was carried out with the use of three points as shown in Fig. 4.

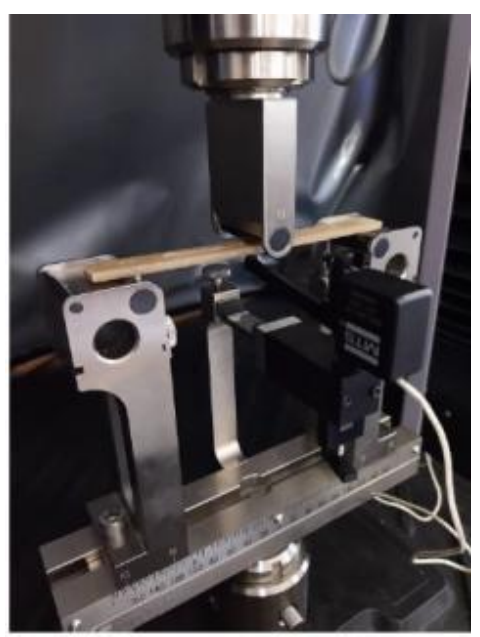

Fig. 4. Bending test.

\section{E. Optical microscopy test}

Optical microscopy was performed using ZEISS optical microscope model AXIO scope A1, at increases of 20X, 50X, 100X. The images were captured at different focal planes for analysis. The analysis was performed on the compound manufactured with five layers.

\section{F. Finite element analysis}

For the finite element analysis, the commercial software Ansys 2020 academic research was used. A static analysis was carried out applying a perpendicular load to the surface of the seat, armrests, and backrest, equivalent to $100 \mathrm{~kg}-\mathrm{f}$ with fixed restrictions at the support points where the pieces would be assembled with screws. The material was assumed to be homogeneous and its properties were defined in the software according to the results obtained from the flexural and stress tensile of the five-layer composite material.

\section{RESULTS}

\section{A. Tensile test.}

As can be seen in Fig. 5, an increase in the tensile mechanical properties of the composite is evidenced with the addition of a quantity of fique fiber.

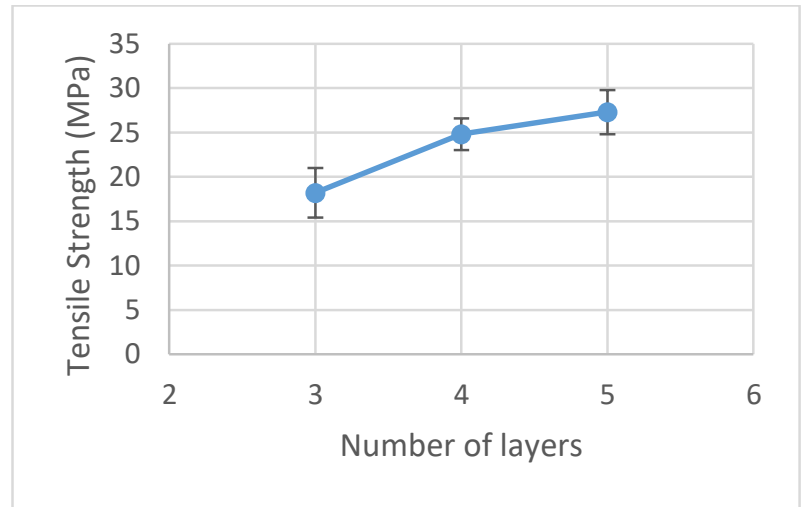

Fig. 5. Tensile strength of composite materials reinforced with fique fibers.

A maximum stress of $27.30 \mathrm{MPa}$ is obtained in the 5-layer composite.

In Fig. 6 the variation of the elasticity module is observed where it is evident that it is increased in the composite with the addition of more quantity of fiber in its manufacture.

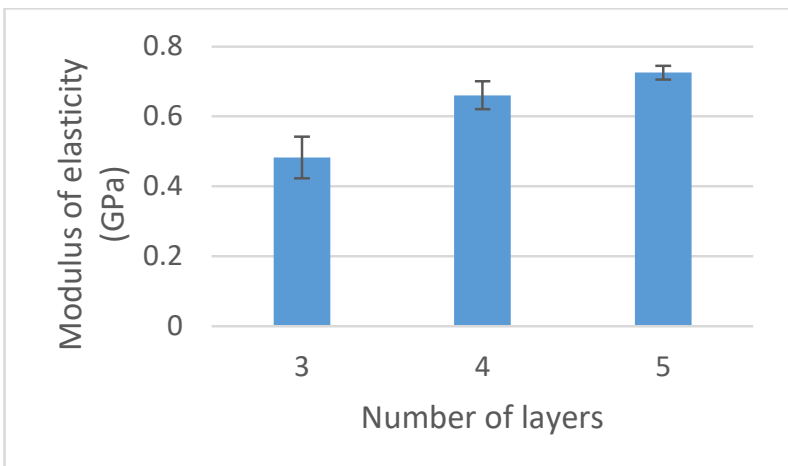

Fig. 6. Modulus of elasticity of composite materials reinforced with fique fibers. 
A maximum modulus of elasticity is obtained in the fivelayer material being $0.725 \mathrm{GPa}$.

The mechanical properties of the tensile stress and the modulus of elasticity increased as more layers of fique were incorporated into the biocomposite, which resulted in the material suffering from a stiffening phenomenon. This behavior was also obtained by Hidalgo et al. [12] in the study of the stress behavior of a composite material with a polyethylene/aluminum matrix, varying the amount of fique used as reinforcement.

According to Gañan et al. [13] chemical treatments to the fique fiber improve the mechanical properties of the composite since it increases the adhesion between the matrix and the fiber. For that reason, for future works it is recommended to apply this type of treatments to the fique.

The results obtained show that the best composite material for the manufacture of the back, seat and armrests of the student chair was the one reinforced with five layers of fique.

\section{B. Flexural test.}

Fig. 7 shows the flexural stress that was obtained when the test was applied to the biocomposite with the different fique layer arrangements.

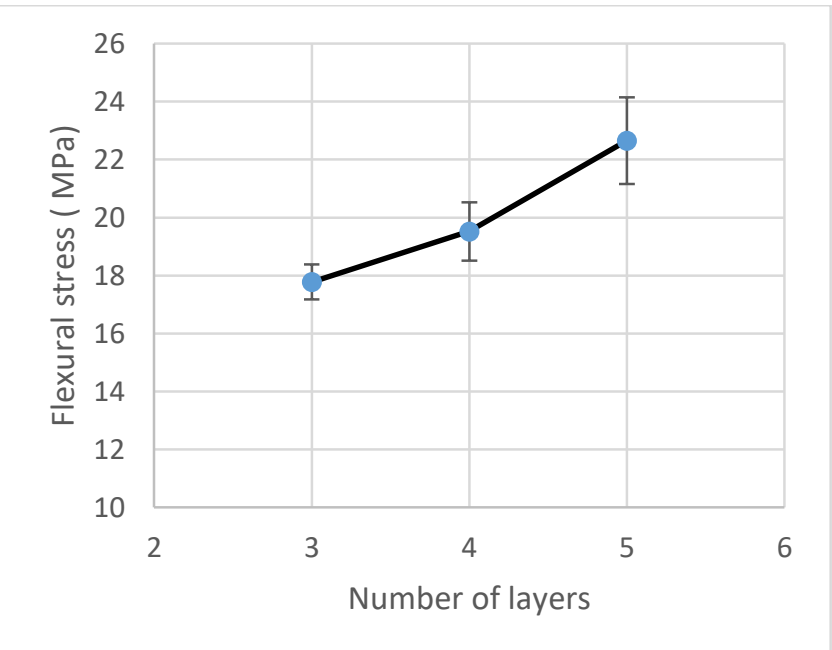

Fig. 7. Flexural stress of composite materials reinforced with fique fibers.

An increase in flexural stress is evidenced with a greater amount of fiber used in the composite, reaching the maximum value of $22.65 \mathrm{MPa}$ with five layers.

This behavior is because the fibers improve the flexural strength of the resins and that there is load transfer [14].

However, the value obtained of flexural stress in the composite materials with fique fiber is lower with respect to those of industrial use, this is due to the low compatibility between the fiber and the matrix for its different chemical nature along the interface [15].

The flexural modulus obtained for the different configurations of layers of composite materials is observed in Fig. 8.

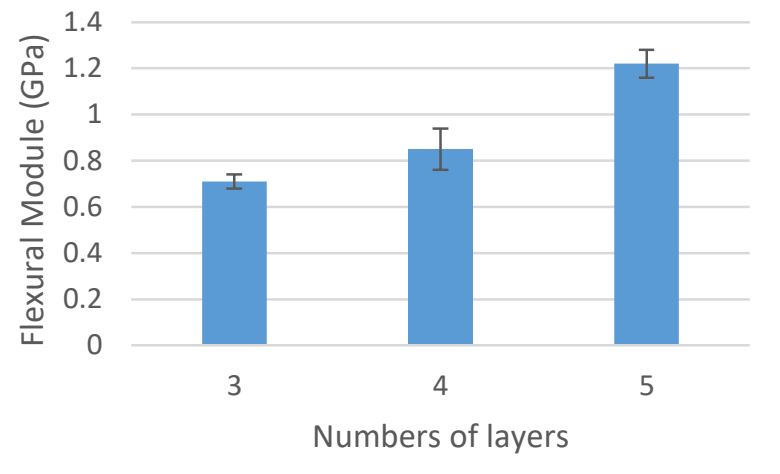

Fig. 8. Flexural module of composite materials reinforced with fique fibers.

An increase in the flexural modulus is observed with the increase in the number of fibers, the highest being $1.22 \mathrm{GPa}$ with the configuration of five layers of fique fibers.

Hidalgo et al. [16] obtained results with the same behavior of increase in the modulus and flexural stress as the percentage of fique fiber increased in the LDPE / $\mathrm{Al}$ matrix composite. Likewise, Hidalgo et al. [17] report the same dynamics of increase in another composite with fique fiber and epoxy and LLDPE matrix.

It is important to emphasize that the properties of the composite reinforced with natural fibers do not depend only on the volume fraction of the fibers, but also on other additional aspects like the orientation and treatment of the fibers, the properties of the matrix and the interfacial adhesion between the fiber and the matrix, in general of the physical and chemical properties of the constituents of the composite [18].

The results obtained show that the best behavior of the composite material subjected to flexural loads for the manufacture of the back, seat and armrests of the student chair, is the material reinforced with five layers of fique.

\section{Optical microscopy.}

Fig. 9 and 10 show the five-layer composite material at 20X and 50X magnification, respectively.

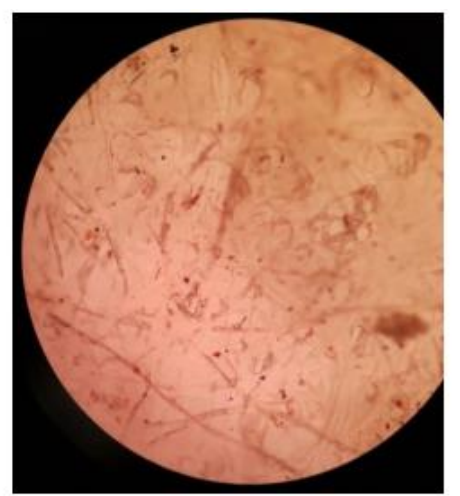

Fig. 9. Micrograph of composite material at 20X. 


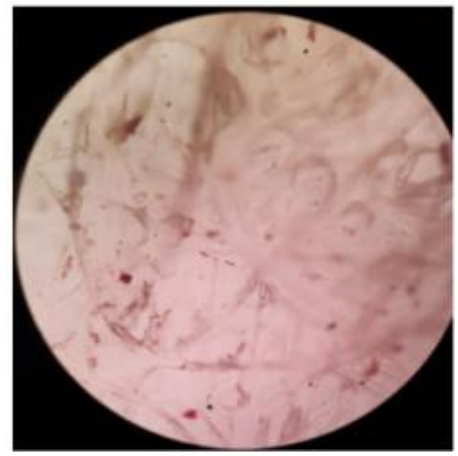

Fig. 10. Micrograph of composite material at 50X.

As shown in the optical microscopy images, there is good adhesion between the fiber and the resin since no defects or spaces between the material's constituents are observed.

In Fig. 11, at 100X magnification, it is evident that the fiber is completely covered by the matrix, which shows that the fique was compatible with the polyester resin.

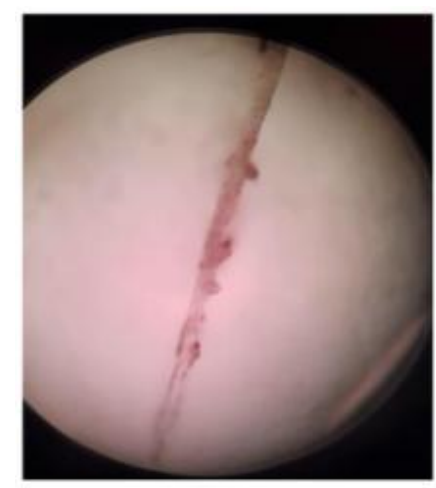

Fig. 11. Micrograph of composite material at 100X.

However, in order to carry out a more conclusive study of the morphology and the interface of the composite, a study should be carried out at higher magnifications using scanning electron microscopy as shown by Barba et al. [19] where they compare micrographs obtained with optical microscopy and SEM technique in composite material with recycled constituents.

\section{Finite element simulation.}

Fig. 12, 13 and 14 [ST1] show the results obtained from the static stress analysis for the seat, armrest and back respectively, carried out in the finite element software Ansys.

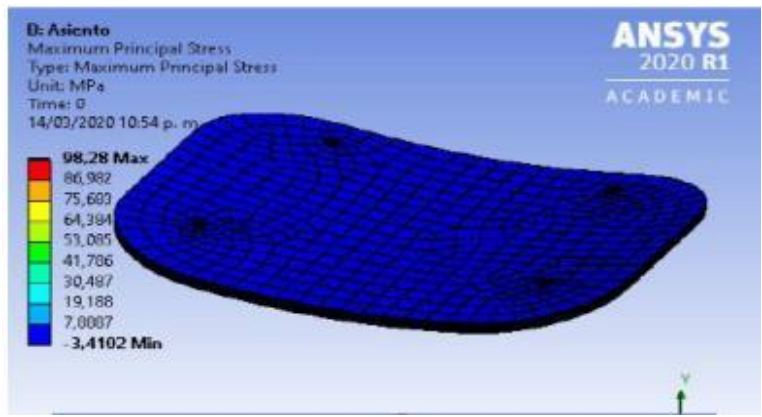

Fig. 12. Seat stress analysis.

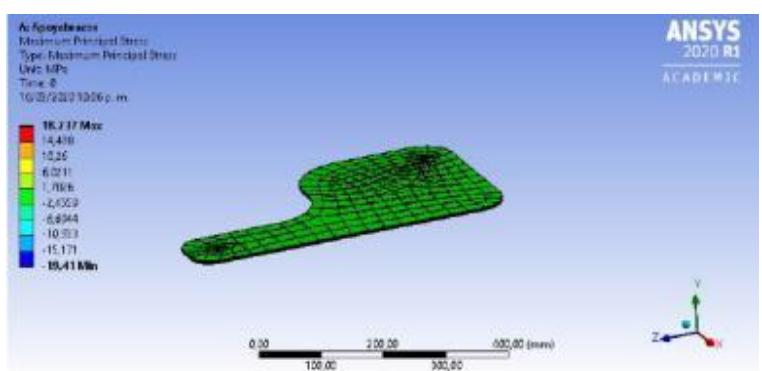

Fig. 13. Armrest stress analysis.

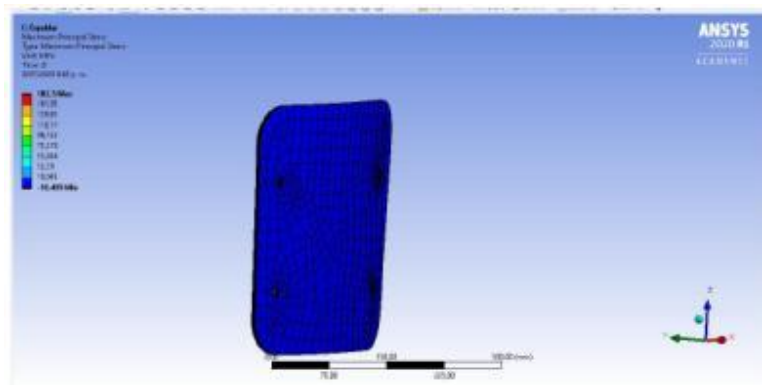

Fig. 14. Back stress analysis.

Additionally, in Fig. 15, 16 and 17, the results obtained from the static analysis in deformation for the seat, armrests and back respectively of the student chair are observed.

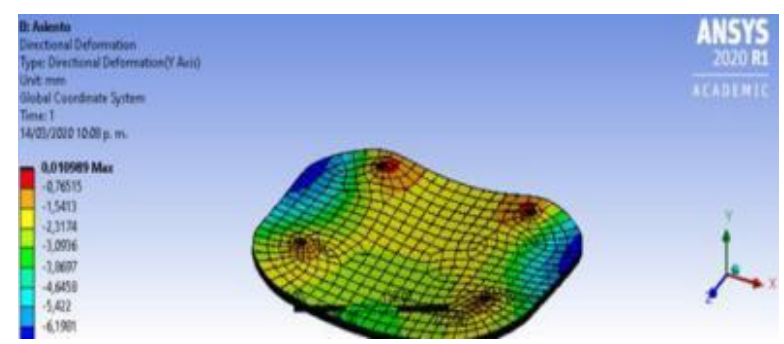

Fig. 15. Seat deformation analysis.

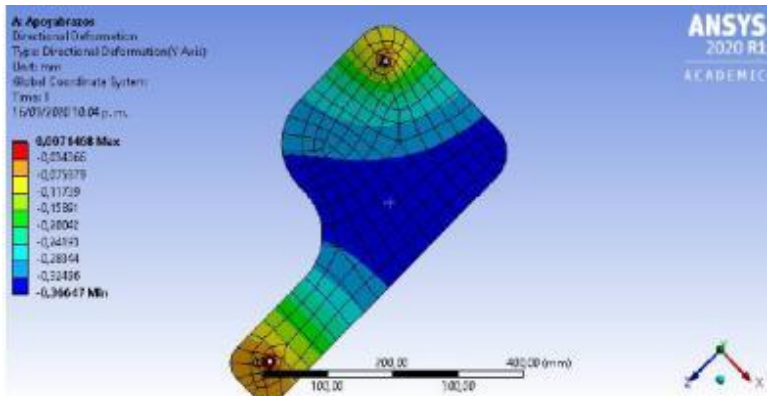

Fig. 16. Armrest deformation analysis. 


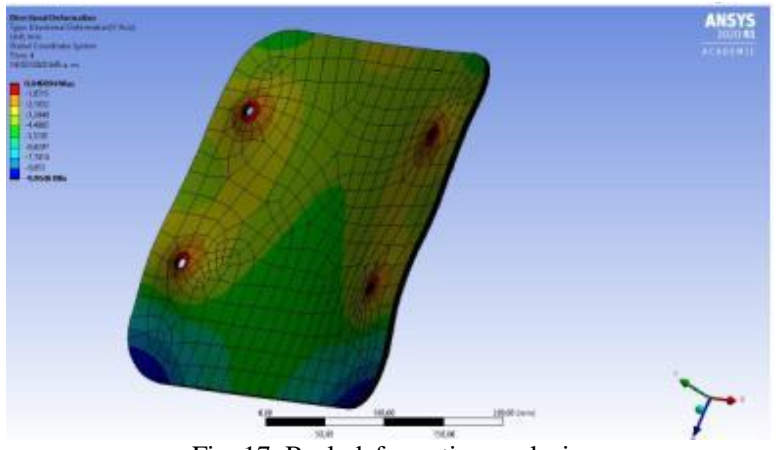

Fig. 17. Back deformation analysis.

The results of the maximum stresses and the deformation of the seat, backrest and armrests are shown in Table I.

TABLE I.

MAXIMUM STRESSES AND DEFORMATIONS

\begin{tabular}{lcc}
\hline \hline \multicolumn{1}{c}{ Part } & Stress (MPa) & Deformation $(\mathrm{mm})$ \\
\hline Seat & 3.4102 & 6.1981 \\
armrests & 6.0211 & 0.36647 \\
backrest & 10.499 & 9.9646 \\
\hline \hline
\end{tabular}

As can be seen in Table I, the maximum stresses obtained through the simulation of finite elements are less than the stresses obtained experimentally for both flexural and tensile, which allows validating that the chair will support the $100 \mathrm{~kg}-\mathrm{f}$ load.

\section{E. Chair manufacturing.}

The fique fiber composite material was laser cut in a random configuration with the geometry of the armrest, seat, and backrest. With this cutting method, the aim was to improve the quality of the final finish of the pieces, avoiding dimensional errors. Fig. 18 shows the laser cut and the different pieces obtained.
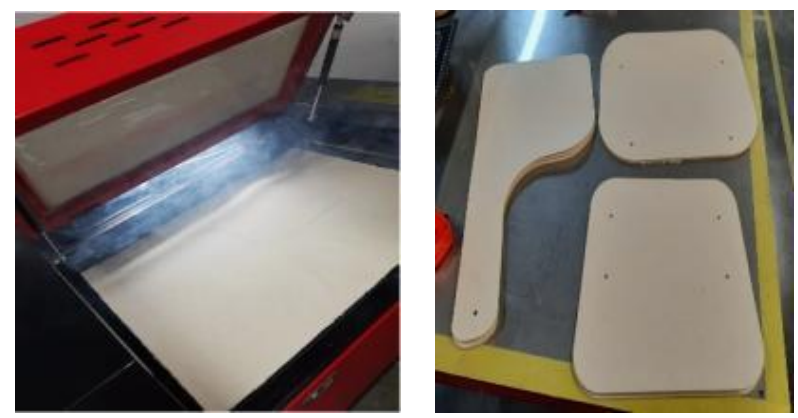

Fig. 18. Laser cutting of parts.

Each of the five layers were impregnated with the polyester resin using a brush, to ensure uniformity on the surface of the fibers. They were then stacked on top of each other using the Hand Lay Up technique. Pressure was applied manually between each of the layers helping to improve the penetration of the matrix into the fiber. Fig. 19 shows the process.

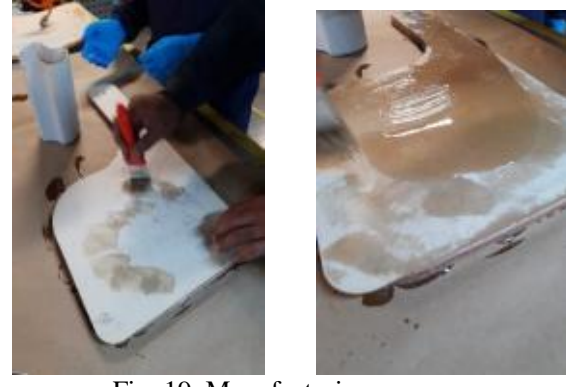

Fig. 19. Manufacturing process.

Curing was done at room temperature $\left(23{ }^{\circ} \mathrm{C}+/-5^{\circ} \mathrm{C}\right)$ for 72 hours. The manufactured seat and armrest parts are shown in Fig. 20.
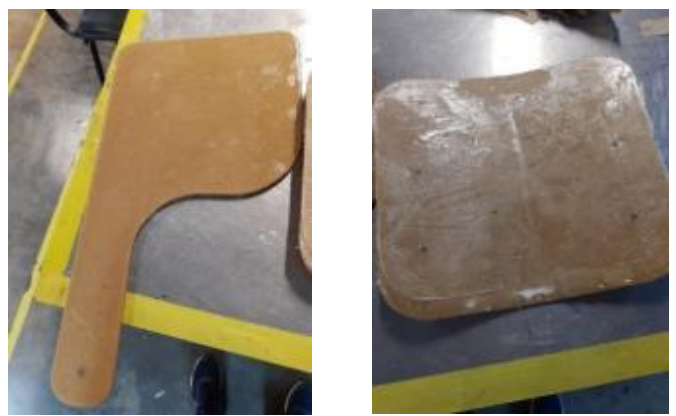

Fig. 20. Armrest and seat manufactured.

For the structure, high density expanded polystyrene molds were made with the geometry of the different parts that make it up.

The different profiles of the chair structure were designed with a diameter of $3 \mathrm{~cm}$. The fiber fabric was impregnated with polyester resin and rolled up on itself ensuring its compactness to be introduced into the mold. Long strips of the fabric were cut to ensure continuous pieces reinforced with the fiber. Fig. 21 shows the manufacturing process used.

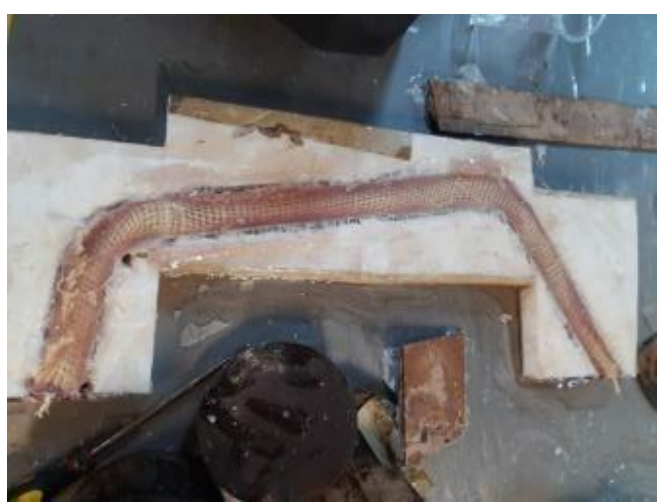

Fig. 21. Manufacturing process of the structure.

The curing of the different profiles was carried out at a room temperature of $24{ }^{\circ} \mathrm{C}+/-8^{\circ} \mathrm{C}$ for 72 hours. Fig. 22 shows the manufactured structure. 


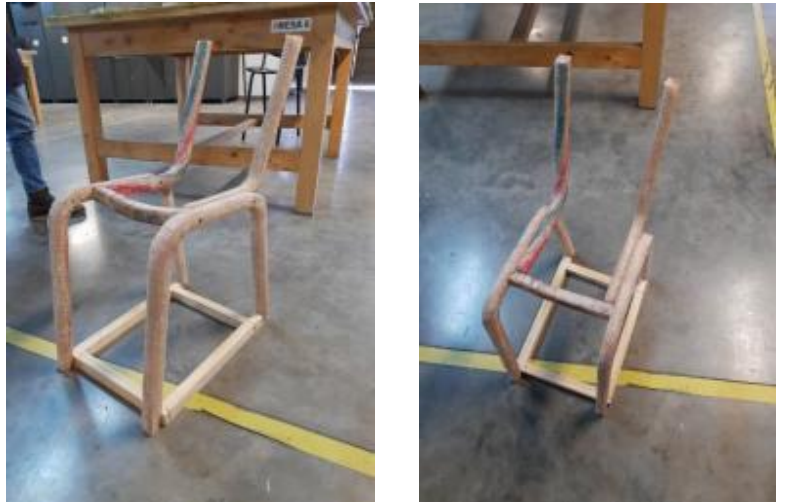

Fig. 22. Structure of the chair.

After all the pieces were made in the composite material with fique fiber, the imperfects present on the surface were eliminated, using 400 and 600 grit sandpaper.

The assembly of the different parts of the chair was carried out using a 2 " self-drilling screw. Fig. 23 shows the chair manufactured.

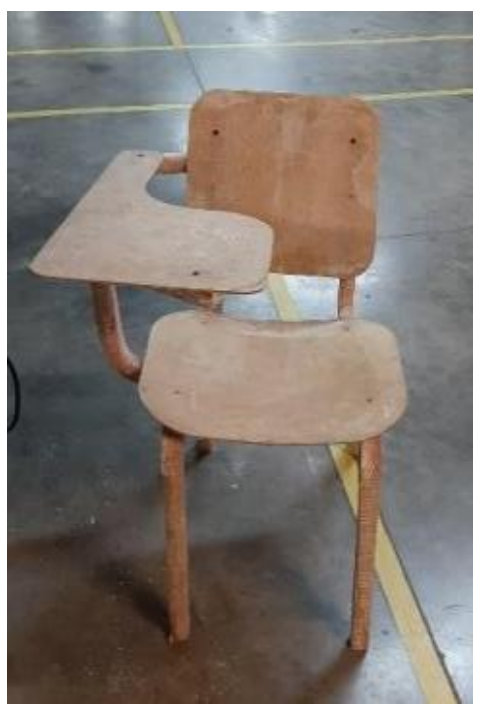

Fig. 23. Manufactured chair.

\section{CONCLUSIONS}

The tensile stress and modulus of elasticity of the composite materials increased with the greater quantity of fibers used, this due to the stiffening of the material, presenting a maximum stress of 27.30 MPa and a maximum modulus of elasticity of $0.725 \mathrm{GPa}$, in the composite material with five layers of fique fiber $(24.9 \%$ by weight of the composite).

Likewise, the mechanical properties to flexion of the composites increased with the insertion of the fiber of fique, the highest stress obtained being $22.65 \mathrm{MPa}$ with a flexural modulus of $1.22 \mathrm{GPa}$ in the composite with five layers of fiber of fique.

The mechanical characterizations showed that the most suitable material for the manufacture of the back, seat and armrests of the student chair was the five layers of fique fiber.

On the other hand, the morphological analysis with optical microscopy allowed observing a good adhesion between fique

fiber and polyester matrix.

With the analysis of finite elements, it was proved that the chair could support the design load of $100 \mathrm{~kg}$-f since the efforts generated in the simulation are lower than those obtained in an experimental way.

A student chair in reinforced composite with five layers of fiber was manufactured by means of the Hand Lay Up manufacturing technique, giving an application to the material of an industrial type.

\section{REFERENCES}

M. Shariff, M. Nagamadhu, M. Jaiprakash, K. Karthikeyan, and Kiran, "Effect of drilling process parameters on natural fiber reinforced basket epoxy composites using grey relational analysis," Mater. Today Proc., vol. 24, pp. 2255-2264, 2019, DOI: 10.1016/j.matpr.2020.03.753.

Y. Jiang, A. L. Yarin, and Y. Pan, "Printable highly transparent natural fiber composites," Mater. Lett., vol. 277, p. 128290, 2020, DOI: 10.1016/j.matlet.2020.128290.

L. Kerni, S. Singh, A. Patnaik, and N. Kumar, "A review on natural fiber reinforced composites," Mater. Today Proc., vol. 28, pp. 16161621, 2020, DOI: 10.1016/j.matpr.2020.04.851.

P. Gañán and I. Mondragon, "Surface modification of fique fibers. Effect on their physico-mechanical properties," Polym. Compos., vol. 23, no. 3, pp. 383-394, 2002, DOI: 10.1002/pc.10440.

D. P. Navia and N. Bejarano, "Evaluación de propiedades físicas de bioplásticos termo-comprimidos elaborados co harina de yuca," Rev. del Inst. Nac. Hig. Rafael Rangel, vol. 12, pp. 40-48, 2014.

G. R. Altoé, P. A. Netto, M. Barcelos, A. Gomes, F. M. Margem, and S. N. Monteiro, "Bending mechanical behavior of polyester matrix reinforced with fique fiber," Charact. Miner. Met. Mater. 2015, pp. 117-121, 2016, DOI: 10.1007/978-3-319-48191-3_14.

P. Gañán and I. Mondragon, "Thermal and degradation behavior of fique fiber reinforced thermoplastic matrix composites," J. Therm. Anal. Calorim., vol. 73, no. 3, pp. 783-795, 2003, DOI: 10.1023/A:1025830430267.

M. S. Oliveira et al., "Statistical analysis of notch toughness of epoxy matrix composites reinforced with fique fabric," J. Mater. Res. Technol., vol. 8, no. 6, pp. 6051-6057, 2019, DOI: 10.1016/j.jmrt.2019.09.079.

S. Gómez, B. Ramón, and R. Guzman, "Comparative study of the mechanical and vibratory properties of a composite reinforced with fique fibers versus a composite with E-glass fibers," Rev. UIS Ing., vol. 17, no. 1, pp. 43-50, 2018, DOI:

https://DOI.org/10.18273/revuin.v17n1-2018004.
S. Delvasto, E. F. Toro, F. Perdomo, and R. M. de Gutiérrez, "An appropriate vacuum technology for manufacture of corrugated fique fiber reinforced cementitious sheets," Constr. Build. Mater., vol. 24, no. 2, pp. 187-192, 2010, DOI: 10.1016/j.conbuildmat.2009.01.010. S. Gómez, B. Ramón, and R. Guzman, "Comparative study of the mechanical and vibratory properties of a composite reinforced with fique fibers versus a composite with E-glass fibers," Rev. UIS Ing., vol. 13, no. 1, pp. 43-50, 2018, DOI: 10.18273/revuin.v17n12018004.

M. A. Hidalgo, M. F. Muñoz, and J. H. Mina, "Influence of Incorporation of Natural Fibers on the Physical, Mechanical, and Thermal Properties of Composites LDPE-Al Reinforced with Fique Fibers," Int. J. Polym. Sci., vol. 2015, 2015, DOI: $10.1155 / 2015 / 386325$.

P. Gañán and I. Mondragon, "Fique fiber-reinforced polyester composites: Effects of fiber surface treatments on mechanical behavior," J. Mater. Sci., vol. 39, pp. 3121-3128, 2004, DOI: 10.1023/B:JMSC.0000025841.67124.c3.

A. Benkhelladi, H. Laouici, and A. Bouchoucha, "Tensile and flexural properties of polymer composites reinforced by flax, jute and sisal fibres," Int. J. Adv. Manuf. Technol., vol. 108, no. 3, pp. 895916, 2020, DOI: 10.1007/s00170-020-05427-2.

G. Canché-Escamilla, J. Rodriguez-Laviada, J. I. Cauich-Cupul, E. Mendizábal, J. E. Puig, and P. J. Herrera-Franco, "Flexural, impact and compressive properties of a rigid-thermoplastic matrix/cellulose 
fiber reinforced composites," Compos. - Part A Appl. Sci. Manuf., vol. 33, no. 4, pp. 539-549, 2002, DOI: 10.1016/S1359835X(01)00136-1.

[16] M. A. Hidalgo, M. F. Muñoz, and K. J. Quintana, "Desempeño mecánico del compuesto polietileno-aluminio reforzado con agro fibras continuas de fique," Rev. Lat. Met. Mat., vol. 31, no. 2, pp. 187-194, 2011.

[17] M. A. Hidalgo-Salazar and J. P. Correa, "Mechanical and thermal properties of biocomposites from nonwoven industrial Fique fiber mats with Epoxy Resin and Linear Low Density Polyethylene," Results Phys., vol. 8, pp. 461-467, 2018, DOI: 10.1016/j.rinp.2017.12.025.

[18] T. Väisänen, O. Das, and L. Tomppo, "A review on new bio-based constituents for natural fiber-polymer composites," J. Clean. Prod., vol. 149, pp. 582-596, 2017, DOI: 10.1016/j.jclepro.2017.02.132.

[19] A. Barba-pingarron and E. Flores-aguilar, "Análisis microscópico para un material compuesto de productos reciclados," Cientifica, vol. 16, no. 2, pp. 83-90, 2012.

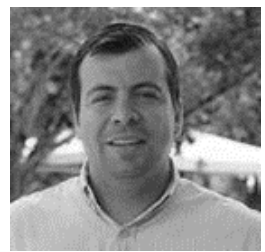

Sergio Andrés Gómez S. Was born in Bucaramanga, Colombia in 1988. He received the B.S in mechanical engineering and industrial engineering from Universidad Pontificia Bolivariana. Magister in industrial engineering from Universidad Pamplona, Colombia. He is currently professor and researcher in the Faculty of Engineering at Universidad Pontificia Bolivariana.

ORCID: https://orcid.org/0000-0002-6425-7062

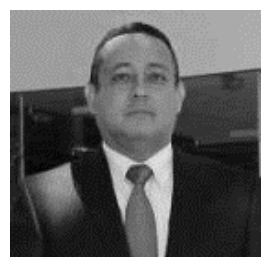

Edwin Córdoba Tuta was born in Bucaramanga, Colombia in 1974. He received the B.S in mechanical engineering from Universidad Industrial de Santander. Magister in Mechanical engineering from Universidad Industrial de Santander, Colombia. He is currently professor and researcher in the Faculty of Engineering at Universidad Pontificia Bolivariana.

ORCID: https://orcid.org/0000-0001-8298-5007

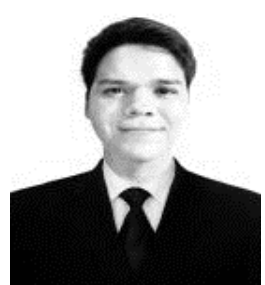

Christian Vega M. Was born in Bucaramanga, Colombia in 1998. He received the B.S in mechanical engineering from Universidad Pontificia Bolivariana in 2020.

ORCID: https://orcid.org/0000-0001-6991-9558

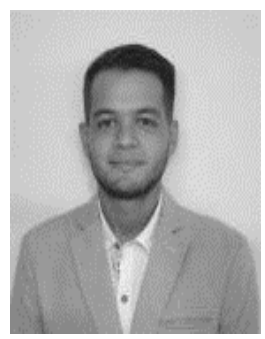

Sergio Andrés Gómez B. Was born in Bucaramanga, Colombia in 1994. He received the B.S in mechanical engineering from Universidad Pontificia Bolivariana in 2020.

ORCID: https://orcid.org/0000-0001-6464-7944 